\title{
Radon Concentration Measurements in Gattar Uranium Prospect, Northern Eastern Desert, Egypt
}

\author{
Naglaa Fahmi \\ Physics Department, Faculty of Science, Alexandria University, Alexandria, Egypt \\ Email: naglafahmi@yahoo.fr
}

How to cite this paper: Fahmi, N. (2019) Radon Concentration Measurements in Gattar Uranium Prospect, Northern Eastern Desert, Egypt. Journal of Analytical Sciences, Methods and Instrumentation, 9, 1-11.

https://doi.org/10.4236/jasmi.2019.91001

Received: October 23, 2018

Accepted: January 7, 2019

Published: January 14, 2019

Copyright $\odot 2019$ by author and Scientific Research Publishing Inc. This work is licensed under the Creative Commons Attribution International License (CC BY 4.0).

http://creativecommons.org/licenses/by/4.0/

\begin{abstract}
The concentration of Radon in mines varies tremendously according to the country rock, type of mineralization and area. Ventilation is also an important factor. The absence of ventilation in mines tends to allow a higher concentration of Radon to build up. This is very dangerous for the miners work inside. In this present work, the radon gas concentration is practically measured in closed uranium prospect mine located at Gabal (G.) Gattar. CR-39 solid state nuclear track detector technique is used. It is found that the radon concentration is around $80 \mathrm{kBq} \mathrm{m}^{-3}$ and an effective ventilation rates should be applied if there will be further works in the future.
\end{abstract}

\section{Keywords}

Radon in Mine, Health Effect of Radon, Radon Gas Concentration, Gabal Gattar, Hurghada, Solid State Nuclear Track Detector,

Applied Effective Ventilation

\section{Introduction}

This mine is in Gabal (the Arabic word for mountain) gattar, which is located at about $35 \mathrm{~km}$ west of Hurghada city, Red Sea coast (Figure 1). It is located at the intersection of latitude $27^{\circ} 5^{\prime} 30^{\prime \prime} \mathrm{N}$ and longitude $33^{\circ} 17^{\prime} 5^{\prime \prime E}$ (Figure 2). Studying this location refers to hosting numerous uranium occurrences namely GI and GII [1] GIII, GIV, GV [2], GVI [3] and G VII [4]. These Uranium occurrences are found at the northern section of G. Gattar granitic pluton and are always associated with strong alteration features such as silicification, hematitization besides kaolinitization, fluoritization, epidotization, chloritization and abundance of manganese denderities [5] [6]. 


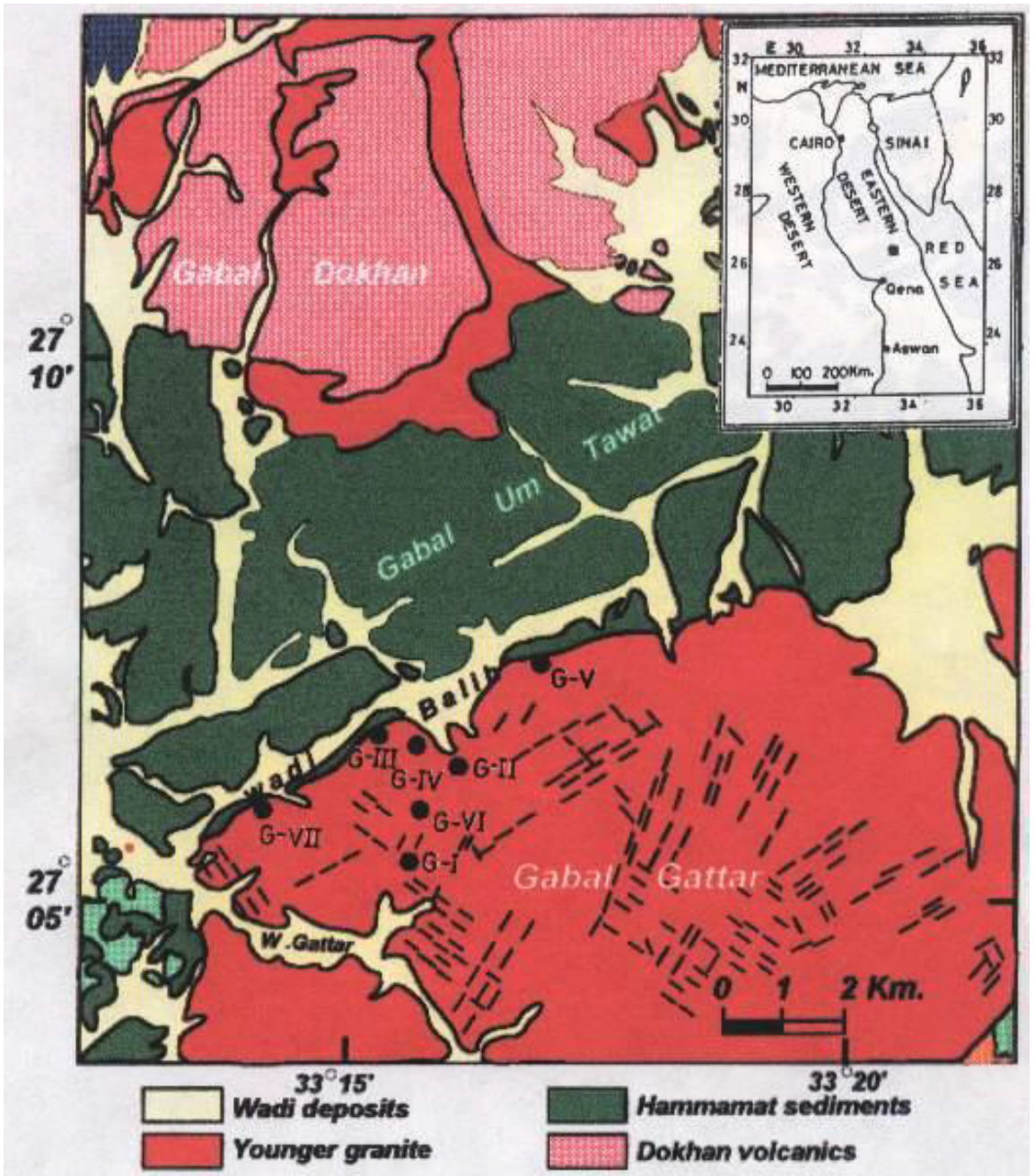

Figure 1. Geologic map of uranium occurrences, Gabal Gattar prospect [5].

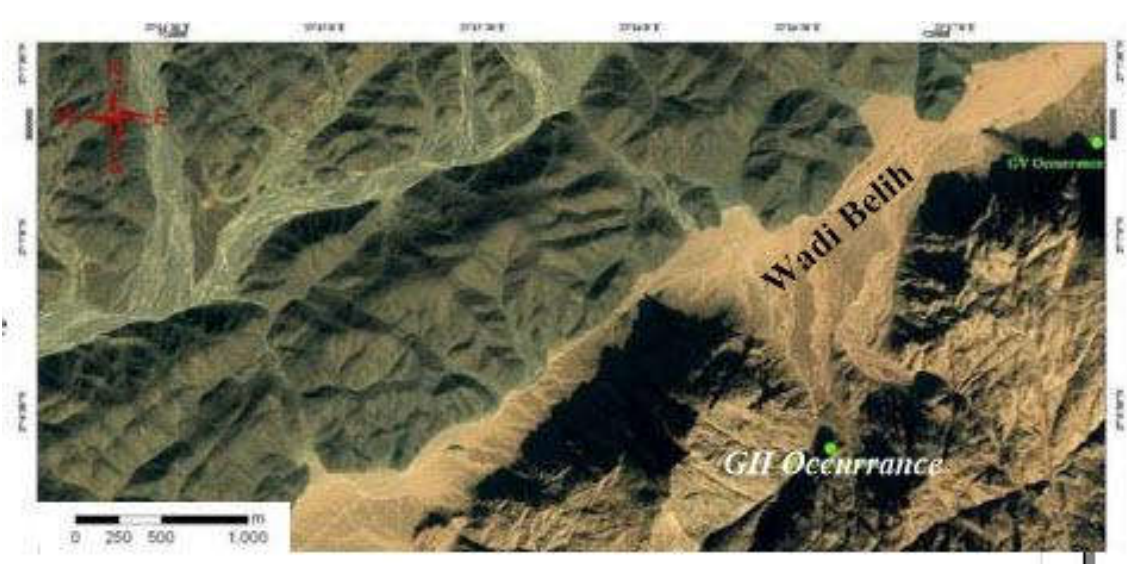

Figure 2. Land sat image for G-II uranium occurrence [6]. Wadi (the Arabic word for ephemeral watercourse).

This work cares about G II (the open pit at G II-occurrence, looking S) which is localized at the western experimental uranium mine GII occurrence (Figure 3(a), Figure 3(b)). The vertical shaft at G II occurrence is shown in Figure 4. 


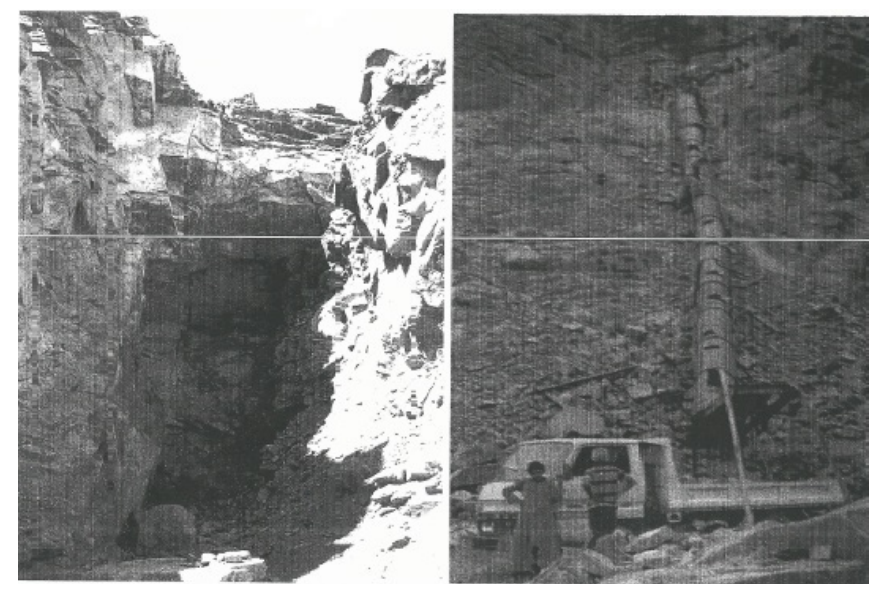

(a)

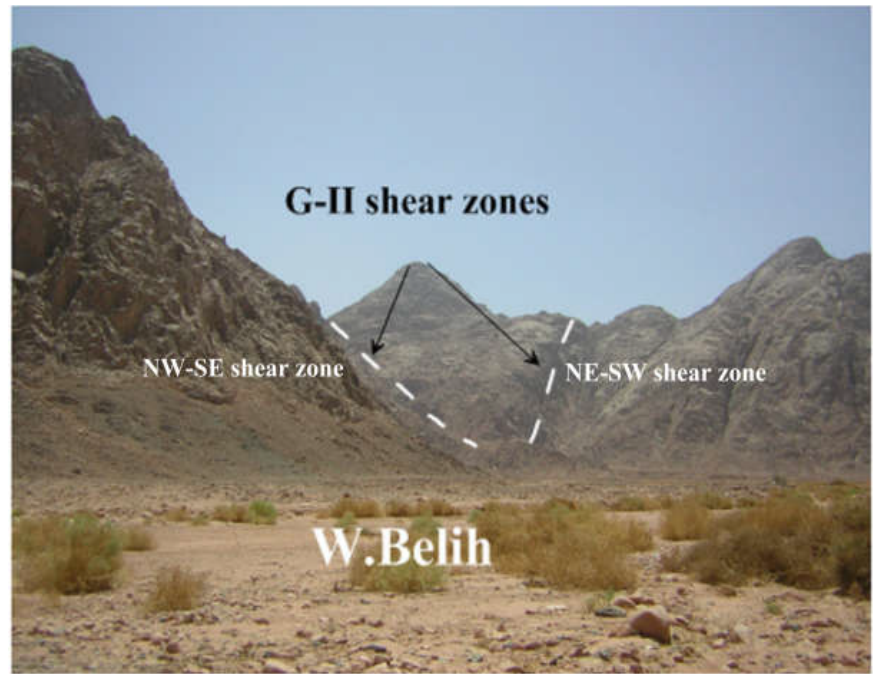

(b)

Figure 3. (a) Open pit at GII occurrence [1]. (b) General view for mineralized shear zones of G-II uranium occurrence, looking SW, G. Gattar area [6].

Uranium minerals and their chemical composition in GII-occurrence are shown in Table 1.

It can be concluded that the main source of natural radioactivity is the high concentration of naturally occurring radionuclides in this mine. The current existing radionuclides include primordial radioisotopes which are ${ }^{238} \mathrm{U},{ }^{235} \mathrm{U}$ and ${ }^{232} \mathrm{Th}$. They are long-lived ones with long half-lives. Also, there are the secondary radionuclides resulting from the decay of primordial radioisotopes. The currently existing long-lived decay series are ${ }^{238} \mathrm{U},{ }^{235} \mathrm{U}$ and ${ }^{232} \mathrm{Th}$. They include 45 radioisotopes.

Uranium is the first element in a long decay series that produces radium and radon. Uranium (in soil and water) is referred to as the parent element, and radium and radon are among daughters. Radium and radon also form daughter elements as they decay. Radon is the only element in the series that is gas. Radon 


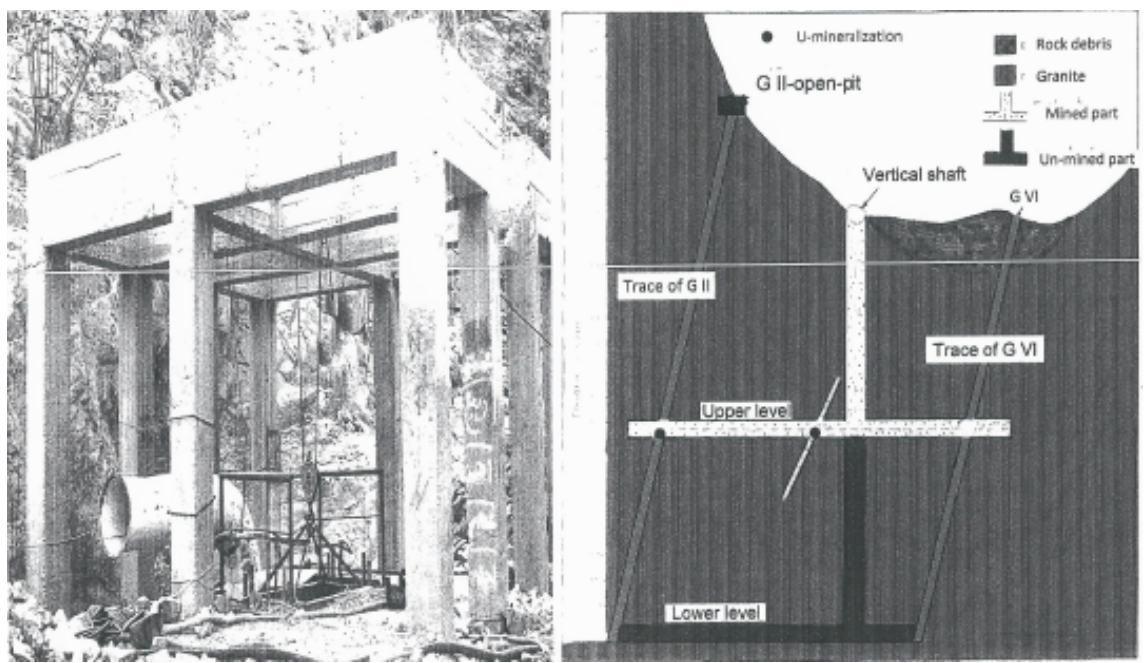

Figure 4. Vertical shaft at GII occurrence [1].

Table 1. The U-mineral and their chemical composition in Gabal Gattar (GII) [4].

\begin{tabular}{cc}
\hline U-mineral & Chemical composition \\
\hline Uranophane and Beta-Uranophane & $\mathrm{CaO}-2 \mathrm{UO}_{2}-2 \mathrm{SiO}_{3}-6 \mathrm{H}_{2} \mathrm{O}$ \\
Kasolite & $\mathrm{Pb}\left(\mathrm{UO}_{2}\right)\left(\mathrm{SiO}_{3}\right)(\mathrm{OH})^{2}$ \\
Clarkite & $\left(\mathrm{Na}, \mathrm{K}, \mathrm{Ca}, \mathrm{PB}_{2} \mathrm{U}_{2} \mathrm{O}_{7} \cdot \mathrm{n} \mathrm{H}_{2} \mathrm{O}\right.$ \\
Zippetite & $2 \mathrm{UO}_{3}-\mathrm{SiO}_{3}-2 \mathrm{H}_{2} \mathrm{O}$ \\
\hline
\end{tabular}

is formed by the natural radioactive decay of uranium in rock, soil, and water.

To operate this mine, the workers are exposed to radon which is, on the average, many times larger than in nature.

In this present work, the radon gas concentration is measured practically in this closed experimental mine located at Gabal (G.). The direct object is to estimate how much ventilation is needed when it will be further activity in the mine.

\section{Health Effects of Radon}

Radon is an odorless, colorless, and tasteless gas. It is a daughter for the radioactive decay of the element radium. Radon is a radioactive gas; it also decays, emitting an alpha particle, and producing polonium.

Radon gas is the main reason for the lung cancer in uranium miners. They are exposed to high levels of the gas during their work [7]. They suffer from higher rates of lung-cancer than the general population. Studying the concentration of radon gas in mine provides not only information on miner's health risk, but also behavior and assessment technique in the environment in general [8]. Lung cancer increases with the increase of cumulative radon exposure above 3200 WLM. Table 2 summarizes the risks studied of radon exposed miners. In addition, the studies show that radon affects in a dangerous way on smokers than non-smokers, but the difference was not statistically significant [8].

Lung cancer due to radon gas in miners is higher than in the general population 
Table 2. Patterns of radon-related lung cancer in miners in the studies considered by the BEIR VI Committee and the study of German uranium miners.

\begin{tabular}{|c|c|c|}
\hline \multicolumn{3}{|c|}{ BEIR VI ${ }^{\mathrm{a}}$ Comittee German ${ }^{\mathrm{b}}$ uranium miners } \\
\hline \multicolumn{3}{|c|}{ ERR/WLM in baseline category ${ }^{c}(\%)$} \\
\hline$\beta$ & 7.68 & 1.35 \\
\hline \multicolumn{3}{|c|}{ Time since exposure } \\
\hline$\theta_{5-14}$ & 1.00 & 1.00 \\
\hline$\theta_{15-24}$ & 0.78 & 1.52 \\
\hline$\theta_{25+}$ & 0.51 & 0.76 \\
\hline \multicolumn{3}{|c|}{ Attained age (years) } \\
\hline$\varphi<55$ & 1.00 & 1.00 \\
\hline$\Phi_{55-64}$ & 0.57 & 0.80 \\
\hline$\Phi_{65-74}$ & 0.29 & 0.66 \\
\hline$\Phi_{75+}$ & 0.09 & 0.49 \\
\hline \multicolumn{3}{|c|}{ Radon concentration (WL) } \\
\hline$\gamma<0.5$ & 1.00 & 1.00 \\
\hline$\gamma_{0.5-1.0}$ & 0.49 & 0.52 \\
\hline$\gamma_{1.0-3.0}$ & 0.37 & 0.36 \\
\hline$\gamma_{3.0-5.0}$ & 0.32 & 0.31 \\
\hline$\gamma_{5.0-15.0}$ & 0.17 & 0.25 \\
\hline$\gamma_{15.0+}$ & 0.11 & 0.12 \\
\hline
\end{tabular}

a'Source: [8]; ' Source: [9]; ' i.e. 5 - 14 years since exposure, attained age $<55$ years, and concentration $<0.5$ WL.

living on radioactive granite terrains. Radon in houses and in closed places like mines is a very dangerous source of lung cancer.

Radon gas decays by alpha particles, which is heavy charged particle with short range in the body and ionizing effect with matter. The principle radiation interaction in the living cells is the reaction with water molecules and the damage occurred to the DNA; which control cellular metabolism and reproduction.

As the alpha particle has very short range in the body, so if radon gas, from indoor air, inhaled in the lung, the alpha particle will completely lose its energy in their tissues producing cancer hazard. So, the biological effect of these alpha particle does not reach cells in any other organs.

Most of the radon gas enter the body by breathing into the lungs and remains for months. The smoker's lung is more affected by radon gas; however, the mechanism remains unclear.

Radon exposure does not cause acute health effect and there are no signs for breathing normal level of radon gas. Health hazard due to radon increases by increasing the exposure. Case studies also show risk of leukemia, chronic lymphocytic, myeloid leukemia and Hodgkin lymphoma are resulted from radon as shown in Table 3 as referred to [10] [11] [12] [13]. 
Table 3. Types of epidemiological studies used to evaluate the risk of lung cancer due to radon exposure [8].

\begin{tabular}{|c|c|c|c|c|}
\hline Study type & Target population & $\begin{array}{l}\text { Main purpose of the } \\
\text { study }\end{array}$ & $\begin{array}{l}\text { Method of } \\
\text { radon dosimetry }\end{array}$ & Major finding/conclusions \\
\hline Cohort studies & Miners/occupational exposure & $\begin{array}{l}\text { Determine the risk of } \\
\text { lung cancer morality } \\
\text { in exposed miners }\end{array}$ & $\begin{array}{l}\text { Radiation exposure was } \\
\text { estimated using } \\
\text { job-exposure matrix } \\
\text { (JEM) which provides } \\
\text { exposure values for } \\
\text { potential alpha energy } \\
\text { from radon and its } \\
\text { progeny in working level } \\
\text { months (WLM) }\end{array}$ & $\begin{array}{l}\text { High levels of radon exposure } \\
\text { were associated with increased } \\
\text { cancer risk. }\end{array}$ \\
\hline Case control studies & The public/residential exposure & $\begin{array}{l}\text { Determine the risk of } \\
\text { lung cancer in } \\
\text { residential setting }\end{array}$ & $\begin{array}{l}\text { Year-long residential } \\
\text { radon levels were } \\
\text { measured by a-track } \\
\text { detectors and were used } \\
\text { to estimate exposure in } \\
\text { the } 25 \text { years prior to the } \\
\text { index date. }\end{array}$ & $\begin{array}{l}\text { Most studies reported small } \\
\text { insignificant association } \\
\text { between residential radon } \\
\text { exposure and lung cancer, } \\
\text { some studies found negative } \\
\text { association. }\end{array}$ \\
\hline $\begin{array}{l}\text { Pooled analysis of } \\
\text { the cohort studies } \\
\text { on miners }\end{array}$ & $\begin{array}{l}\text { Obtain summary estimates of } \\
\text { the risk of lung cancer in } \\
\text { radon-exposed miners using } \\
\text { large sample size. }\end{array}$ & $\begin{array}{l}\text { A summary of the } \\
\text { WLM exposure was } \\
\text { obtained for the total } \\
\text { subjects using } \\
\text { reported exposure } \\
\text { levels in the } \\
\text { individual studies. }\end{array}$ & $\begin{array}{l}\text { A summary of the WLM } \\
\text { exposure was obtained } \\
\text { for the total subjects } \\
\text { using reported exposure } \\
\text { levels in the individual } \\
\text { studies. }\end{array}$ & $\begin{array}{l}\text { A consistent linear } \\
\text { relationship for cumulative } \\
\text { radon progeny and lung } \\
\text { cancer was observed in the } \\
\text { range of miner exposures }\end{array}$ \\
\hline $\begin{array}{l}\text { Combined analysis } \\
\text { of case-control } \\
\text { studies }\end{array}$ & $\begin{array}{c}\text { The general public/residential } \\
\text { exposure in Europe and North } \\
\text { America }\end{array}$ & $\begin{array}{l}\text { Obtain accurate } \\
\text { estimates of lung } \\
\text { cancer risk from } \\
\text { residential radon } \\
\text { exposure by reducing } \\
\text { incertainity in radon } \\
\text { dosimetry }\end{array}$ & $\begin{array}{c}\text { Available radon } \\
\text { measurements form } \\
\text { individual studies were } \\
\text { used to estimate radon } \\
\text { exposure for the total } \\
\text { individuals in all homes } \\
\text { occupied over the past } \\
5 \text { - } 30 \text { years. }\end{array}$ & $\begin{array}{l}\text { A significant increase in risk of } \\
\text { lung cancer was associated } \\
\text { with increased radon } \\
\text { exposures with seemingly } \\
\text { linear dose-response } \\
\text { relationship. }\end{array}$ \\
\hline
\end{tabular}

Mines have a special case because they have a high concentration of radon gas. Mines characterized by a static environment with stable temperature and humidity. Types of rocks and quality of water in mine are the main parameters that affect the radon concentration in mines.

Controlling of radon and its daughters is very important during the choice of mining method, mine layout and planning the ventilation system. The health hazard of high exposure to radon is a very serious problem in the mining of uranium. So, ventilation is very important to control the radon concentration which have different results at different positions in the same mine. In addition, the lower the atmospheric pressure, the greater rate of drawing out of radon from the rock [14].

It is found that the hazard of lung cancer deaths is present after exposure by 50 WLM [15]. The working level month (WLM) represents the amount of radiation accumulated by working in a radon daughter concentration of $1 \mathrm{WL}$ for 170 
hours working. Ventilation and dust control have been used to reduce the risk occupationally induced cancer from radon. All these procedures minimize the miners' exposure to radon gas than in the early years of mining [16]. It is the best way to protect miners. At present, the radon level in Chinese uranium mines has the lowest value [17]. As the ventilation is very important, many researchers are still working to improve the conditions, increase operational efficiency and reduce costs [18] [19] [20].

\section{Experiments}

In this present work, a series of CR-39 detectors were attached to a bottom of stainless steel can (covered by a thin membrane to let only the radon gas enter to the detector) and hanged up to the ceiling of the mine (=1 $\mathrm{m}$ from the ground surface) in the places shown in Figure 5. Two other detectors (A and B) are located outside to determine the background or better the outside radon concentration.

The detectors were exposed for a month (30 days). They were collected and etched in $6.25 \mathrm{M} \mathrm{NaOH}$ at $70^{\circ} \mathrm{C}$. The track number was counted using an optical microscope attached to a CCD Camera. The track densities are converted into radon concentrations $\left(\mathrm{Bq} \mathrm{m}^{-3}\right)$ using the calibration factor of 5.4 tracks $\mathrm{cm}^{-2}$ per $\mathrm{kBq} \mathrm{h} \cdot \mathrm{m}^{-3}[21]$. The conversion between radon air concentration and the lung dose received by a person is calculated by the generally accepted equivalence of $50 \mu \mathrm{Sv} / \mathrm{y}$ per $1 \mathrm{~Bq} / \mathrm{m}^{3}$ for miners. A, B are samples were exposed in two open air background places out of the mine under investigation. The radon concentration was found to be $4.81 \mathrm{kBq} \mathrm{m}^{-3}$ and $10.18 \mathrm{kBq} \mathrm{m}^{-3}$, respectively. Data are shown in Table 4. It shows the U-concentration in ppm at the chosen points in the mine under investigation.

This previous experimental steps were repeated in the mine after applying the ventilation process and cleaning dust. All the detector samples recorded negligible number of tracks. It is found that the radon concentration for different places

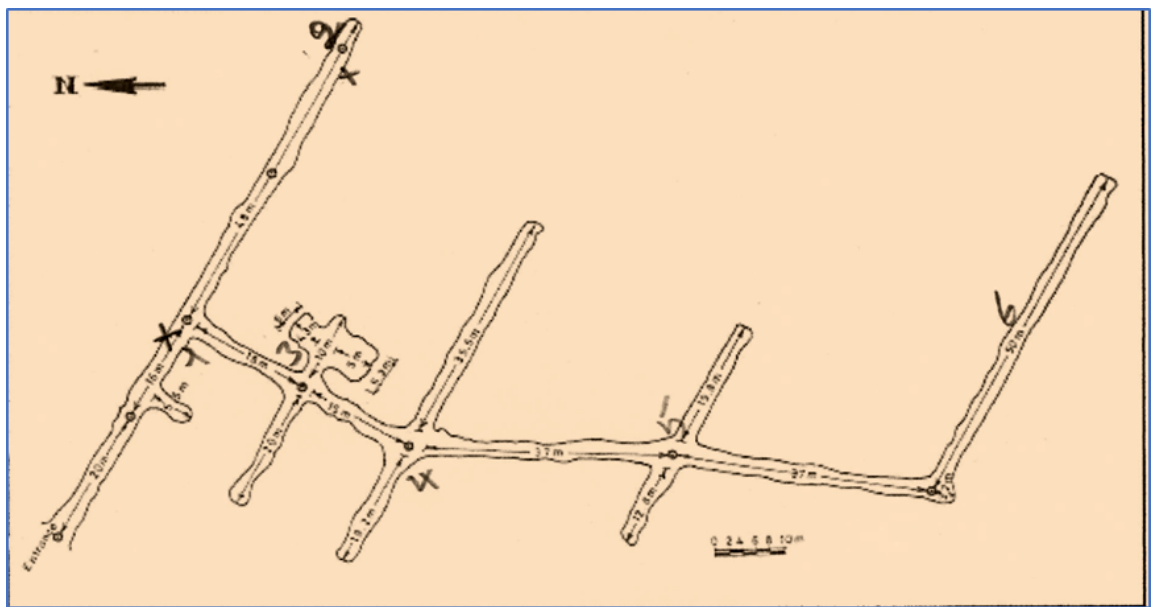

Figure 5. The planimetric map of GII Northern Tunnel G. Gattar project with the places of the radon gas detectors. 
Table 4. Radon concentration in different places inside the mine.

\begin{tabular}{cccccc}
\hline & $\begin{array}{c}\text { Total } \\
\text { radioactivity }\end{array}$ & $\mathrm{K}(\mathrm{ppm})$ & $\mathrm{U}(\mathrm{ppm})$ & $\mathrm{Th}(\mathrm{ppm})$ & $\begin{array}{c}\text { Radon concentration } \\
\left(\mathrm{kBq}^{-3}\right)( \pm 9 \%)\end{array}$ \\
\hline 1 & 1600 & 6.6 & 58 & 40 & 87.41 \\
2 & 1300 & 6.2 & 43.4 & 36.5 & 75.44 \\
3 & 5560 & 6.9 & 210 & 49 & B.D.L. $^{*}$ \\
4 & 1700 & 7.1 & 59 & 41 & B.D.L.* \\
5 & 2810 & 8.2 & 92.5 & 43.9 & B.D.L ${ }^{*}$ \\
6 & 1200 & 6.7 & 36.3 & 41.4 & 54.63 \\
\hline
\end{tabular}

${ }^{*}$ B.D.L.: Beyond Detection Limit.

inside the mine is ranging between 38 and $44 \mathrm{~Bq} / \mathrm{m}^{3}$.

To estimate the annual effective doses, one must consider the conversion coefficient from absorbed dose in air to effective dose and the indoor occupancy factor. In the 2000, the UNSCEAR [22] Report, a value of $9.0 \mathrm{nSv} \mathrm{h}^{-1}$ per Bq m${ }^{-3}$ was used for the conversion factor (effective dose received by adults per unit ${ }^{222} \mathrm{Rn}$ activity per unit of air volume), 0.4 for the equilibrium factor of ${ }^{222} \mathrm{Rn}$ indoors and 0.8 for the indoor occupancy factor. Hence, the effective dose rate indoors in units of $\mathrm{m} \mathrm{Sv}^{-1}, \mathrm{H}_{\mathrm{E}}$, is calculated by the following formula:

$$
H_{E}=C_{R n} \text {. F.T.D }
$$

where $C_{R n}$ is the measured ${ }^{222} \mathrm{Rn}$ concentration (in $\mathrm{Bq} \mathrm{m}{ }^{-3}$ ), $\mathrm{F}$ is the ${ }^{222} \mathrm{Rn}$ equilibrium factor indoors (0.4), $\mathrm{T}$ is the indoor occupancy time $(0.8 \times 24 \mathrm{~h} \times 365.25=$ $\left.7010 \mathrm{hy}^{-1}\right)$, and $\mathrm{D}$ is the dose conversion factor $\left(9.0 \times 10^{-6} \mathrm{mSv} \mathrm{h}^{-1}\right.$ per Bq $\left.\mathrm{B}^{-3}\right)$. As an arithmetic example, for a measured ${ }^{222} \mathrm{Rn}$ concentration of $40.0 \mathrm{~Bq} \mathrm{~m}^{-3}$ the above formula yields an effective dose equivalent to the population which is equal to $1.0 \mathrm{mSv} \mathrm{y}^{-1}$.

The average annual effective dose equivalent from different places in the mine has been calculated using equation 1 to be $1.2 \pm 0.23 \mathrm{mSv} \mathrm{y}^{-1}$.

By comparing these radon concentrations by values recommended by the ICRP [23], we find that they are very high and risky for workers. Consequently, the annual exposure and the annual effective dose are very high. Another important parameter must be considered, it is the fatality coefficient. This parameter represents the life time fatality risk; it is calculated per WLM per year. The recommended value by ICRP for this parameter is $3 \times 10^{-4} \mathrm{WLM}^{-1}$ for the public and workers [24]. This value is the life time risk from chronic occupational exposure for workers. It is considered if the scenario is a constant low-level exposure to 2 WLM per year during adulthood from 18 to 65 years [24]. These parameters were estimated based on chronic occupational exposure to the radon gas, which is calculated usingICRP-65 [23] [24].

\section{Conclusions}

The radon gas concentration is studied in the uranium mine located at Gabal Gattar uranium prospect. If this mine is on work, the radon gas is controlled by 
applying effective ventilation. After stopping working and closing the mine, the radon gas concentration raises to be higher than the action level of $1000 \mathrm{~Bq} \mathrm{~m}^{-3}$. It is suggested that effective ventilation rates should be applied to reduce the radon concentration when starts working in future.

The effective ventilation is calculated as $1 \mathrm{~m}^{3}$ for each square meter of the front of the mine. This is calculated by the exhaust air coming out at the mine entrance.

The ventilation effect is obvious when one compares the radon concentration in different places inside the mine and the corresponding value at the tow position $\mathrm{A}$ and $\mathrm{B}$ outside the mine.

As the work is going along, the length of the mine is gradually increasing so that we can determine how much of air out at the entire mine front. The condition of ventilation is varied each time according to the quantity of dust aiming to reach to the clean atmosphere to protect the miners' health.

To be ideal as possible, ventilation system must be involved from the first step of mine design to prevent the risk of over cost corrections. It is very useful also to train the ventilation staff.

After all these precautions of ventilation, the mine starts to be on work, it is found that the radon gas in the mine is reduced to realize the permissible average annual effective dose equivalent.

Finally, it can be concluded that the average annual exposure of uranium miners have fallen to level similar to the concentration inhaled in nature.

\section{Acknowledgements}

The author is grateful to Prof. Dr. Mahmoud H. Shalaby for his help, assistance and supporting with the geological information. He is also very acknowledged for constructive criticism.

\section{Conflicts of Interest}

The authors declare no conflicts of interest regarding the publication of this paper.

\section{References}

[1] Salman, A.B., El Aassy, I.E. and Shalaby, M.H. (1990) New Occurrence of Uranium Mineralization in Gabal Gattar, Northern Eastern Desert, Egypt. Annual Geological Survey. Egypt, XVI, 31-34.

[2] Shalaby, M.H. (1990) Uranium Mineralization in Northern Gebel Qatter Locality, Northern Eastern Desert. 7th Conference. Phanerozoic and Development. Al Azhar University, Cairo.

[3] Abu Zeid, M. (1995) Relation between Surface and Surface Uranium Mineralization and Structural Features. Gebel Qattar, North Eastern Desert, Egypt. M.Sc. Thesis, Ain Shams University, 208 p.

[4] Shalaby, M.H. (1995) New Occurrence of Uranium Mineralization G VII, Gabal Qattar Uranium Prospect, Northern Eastern Desert, Egypt. Bulletin Faculty of 
Science. Alexandria University, 35, 447-460.

[5] Ghobrial, M.G. and Lotfi, M. (1967) The Geology of Gebel Gattar and Gebel Dokhan Area. General Egyptian Organization for Geological Research and Mining, Cairo, Egypt, Paper No. 40, 26 p.

[6] Waheeb, A.G. (2017) Detailed Structural Analysis for the Mineralized Shear Zones of G-II Uranium Occurrence at Gabal Gattar Younger Granite Northern Eastern Desert Egypt. International Journal of Innovations in Engineering and Technology (IJIET), Special Issue on EGE 2017.

[7] Durrani, S.A. and Ilic, R. (1997) Radon Measurements by Etched Track Detectors, Applications in Radiation Protection, Earth Sciences and the Environment. World Scientific Publishing, Singapore.

[8] Biological Effects of Ionizing Radiation (BEIR) VI. 1999 Committee on the Health Risks of Exposure to Radon, Board on Radiation Effects Research. US National Research Council. National Academic Press, Washington DC.

[9] Grosche, B., Kreuzer, M., Kreisheimer, M., Schnelzer, M. and Tschense, A. (2006) Lung Cancer Risk among German Male Uranium Miners: A Cohort Study, 1946-1998. British Journal of Cancer, 95, 1280-1287.

https://doi.org/10.1038/sj.bjc.6603403

[10] Lubin, J.H., Linet, M.S., Boie, J.D., Buckley, J., Conrath, S.M., Hatch, E.E., Kleinerman, R.A., Tarone, R.E., Wacholder, S. and Robison, L.L. (1998) Case-Control Study of Childhood Acute Lymphoblastic Leukemia and Residential Radon Exposure. Journal of the National Cancer Institute, 90, 294-300. https://doi.org/10.1093/jnci/90.4.294

[11] Law, G.R., Kane, E.V., Roman, E., Smith, A. and Cartwright, R. (2000) Residential Radon Exposure and Adult Acute Leukaemia. Lancet, 355, 1888. https://doi.org/10.1016/S0140-6736(00)02300-X

[12] Darby, S.C., Whitley, E., Howe, G.R., Hutchings, S.J., Kusiak, R.A., Lubin, J.H., Morrison, H.I., Tirmarche, M., Tomasek, L., Radford, E.P., Roscoe, R.J., Samet, J.M. and Yao, S.X. (1995) Radon and Cancers Other than Lung-Cancer in Underground Miners-A Collaborative Analysis of 11 Studies. Journal of the National Cancer Institute, 87, 378-384. https://doi.org/10.1093/jnci/87.5.378

[13] Rericha, V., Kulich, M., Rericha, R., Shore, D.L. and Sandler, D.P. (2006) Incidence of Leukemia, Lymphoma, and Multiple Myeloma in Czech Uranium Miners: A Case-Cohort Study. Environmental Health Perspectives, 114, 818-822. https://doi.org/10.1289/ehp.8476

[14] Kiesa, B.A. and Rowlinson, L. (1996) Radon Survey in the Grand-Duchy of Luxembourg-Indoor Measurements Related to House Features, Soil, Geology and Environment. Environment International, 22, 805-808. https://doi.org/10.1016/S0160-4120(96)00187-0

[15] Toxological Profile for Radon (1990) Agency for Toxic Substances and Disease Registry, US Public Health Service, in Collaboration with US Environmental Protection Agency.

[16] UNSCEAR (2006) Report Vol. I. United Nations Scientific Committee on the Effects of Atomic Radiation UNSCEAR 2006 Report to the General Assembly, with Scientific Annexes.

[17] Hu, P.H. and Li, X.J. (2012) Analysis of Radon Reduction and Ventilation Systems in Uranium Mines in China. Journal of Radiological Protection, 32, 289-300. https://doi.org/10.1088/0952-4746/32/3/289 
[18] Goldberg, A. (2016) The Economic Impact of Load Shedding: The Case of South African Retailers.

[19] Chatterjee, A., Zhang, A.L. and Xia, X. (2015) Optimization of Mine Ventilation Fan Speeds According to Ventilation on Demand and Time of Use Tariff. Applied Energy, 146, 65-73.

[20] Smit, N.J. (2017) Reducing Electrical Costs for a Mine Ventilation System with the Aid of Simulation Software. Dissertation Submitted in Fulfillment of the Requirements for the Degree Master of Engineering in Electrical and Electronic Engineering at the Potchefstroom Campus of the North-West University.

[21] Isne, A., Okten, G. and Celebi, N. (2005) Radon Concentration Measurements in Bituminous Coal Mines. Radiation Protection Dosimetry, 113, 173-177.

https://doi.org/10.1093/rpd/nch449

[22] UNSCEAR (2000) Sources and Effects of Ionizing Radiation-United Nations Scientific Committee on the Effects of Atomic Radiation. UNSCEAR 2000 Report to the General Assembly with Scientific Annexes, United Nations, New York.

[23] International Commission on Radiological Protection (1991) ICRP Publication 60. Annals of the ICRP 21.

[24] International Commission on Radiological Protection (1993) ICRP Publication 65. Ann. ICRP 23 (2). Pergamon Press, Oxford. 